\title{
PERLINDUNGAN HUKUM BAGI PEREMPUAN EKONOMI LEMAH DALAM UPAYA PENCEGAHAN TERJADINYA KEKERASAN DALAM RUMAH TANGGA DI KELURAHAN TEGALGEDE KECAMATAN SUMBERSARI KABUPATEN JEMBER
}

\author{
Oleh : \\ Solehati Nofitasari, Email : Solihatinofitasari@yahoo.co.id \\ Supianto, Email : supianto@uij.ac.id
}

\begin{abstract}
The household is a small part of a society. A person's goal in fostering a home is to be happy, safe and secure. In realizing this, it depends on each individual in a household, especially in the attitude, behavior and self-control of everyone in the household. the factors that cause the most domestic violence is caused by economic factors, this is because the Tegalgede Village is one of the urban areas in the urban area so that the needs are quite a lot but their income does not match the expenditure. This is because their husband's job is only construction workers and shop employees. While obstacles in law enforcement in the event of acts of violence in the household namely due to violence in the household is still considered a family disgrace that should not be told or conveyed to other parties. So many victims of domestic violence, especially women, are reluctant to tell or report violence that has happened to him. Prevention efforts that they do is just to accept the violence that occurred against him.
\end{abstract}

Keywords : Legal Protection, Poor Women, Domestic Violence 


\section{PENDAHULUAN}

\subsection{Latar Belakang}

Negara Republik Indonesia adalah negara yang berdasarkan Ketuhanan Yang Maha Esa, dengan demikian, setiap orang dalam lingkup rumah tangga untuk melaksanakan hak dan kewajibannya harus didasari oleh agama dan nilai kemanusiaan. Hal ini penting ditumbuh kembangkan dalam rangka membangun keutuhan rumah tangga.Rumah tangga merupakan bagian kecil dari suatu masyarakat. Tujuan seseorang membina rumah tangga adalah bahagia, aman, dan tentram.

Dalam mewujudkan hal tersebut, bergantung pada setiap individu dalam satu lingkup rumah tangga, terutama dalam bersikap, perilaku dan pengendalian diri setiap orang di lingkup rumah tangga tersebut. Keutuhan dan kerukunan dalam rumah tangga dapat terjadi jika masingmasing individu mampu bersikap dan berprilaku dengan baik serta tidak ada campur tangan dari pihak manapun. Begitu juga sebaliknya keutuhan rumah tangga akan runtuh apabila sikap menyayangi, saling menghormati dan gannguan dari pihak luar rumah tangga tidak dapat terkontrol dengan baik. Sehinga pada akhirnya dapat menyebabkan timbulnya kekerasan dalam rumah tangga.
Berdasarkan data yang dihimpun dari lembaga Pusat Pelayananan Terpadu Kabupaten Jember dimana lembaga ini adala lembaga layanan pendampingan bagi perempuan dan anak korban kekerasan, untuk jumlah kekerasan dalam rumah tangga setiap tahunnya mencapai 20 kasus namun data ini bukan lah data KDRT untuk seluruh kabupaten Jember karena PPT hanyalah salah satu lembaga layanan dan masih banyak lembaga layanan pendampingan yang ada dikabupaten Jember. Dari jumlah data tersebut jenis KDRT bermacam macam ada yang kekersan fisik, kekerasan psikis, kekerasan seksual dan juga penelantaran. Faktor yang melatar-belakangi pun juga beragam ada yang dikarenakan phak ketiga, ekonomi, pendidikan dan masih banyak lagi faktor yang lain.

Pemerintah Indonesia telah memiliki dasar hukum untuk melindungi terjadinya kekerasan dalam rumah tangga, salah satunya adalahUndang-Undang Nomor 23 Tahun 2004 Tentang Penghapusan Kekersan Dalam Rumah Tangga. Namun sayangnya UU KDRT ini belum cukup untuk memberikan perlindungan bagi korban sehingga masih banyak korban tidak mendapatkan keadilan terutamnya bagi kaum perempuan dengan ekonomi lemah. Perempuan dengan ekonomi lemah sangat rentan menjadi korban disebabkan oleh karena tingkat pendidikan yang 
rendah, informasi dan pengetahun sangat minim serta mengapa mereka juga sanat rentan menjadi korban karena secara ekonomi mereka tergantuk pada pihak laki-laki.

Dalam Pasal 2 Undang-Undang Nomor 23 Tahun 2004 disebutkan bahwa lingkup rumah tangga dalam undangundang ini meliputi :

a. Suami, istri, dan Anak

b. Orang-orang yang mempunyai hubungan keluarga dengan orang sebagaimana dimaksud pada huruf (a) karena hubungan darah, perkawinan, persusuan, pengasuhan, dan perwalian yang menetap dalam rumah tangga dan

c. Orang yang bekerja membantu rumah tangga dan menetap dalam rumah tangga yang bersangkutan.

Berdasarkan latar belakang diatas maka kami tertarik untuk melakukan penelitian perlindungan hukum bagi perempuan ekonomi lemah dalam upaya pencegahan terjadinya KDRT Di Kelurahan Tegalgede sehingga kaum perempuan yang menjadi korban mengetahui apa yang menjadi hak mereka serta perlindungan apa saja yang harusnya didapat oleh mereka.

\subsection{Rumusan Masalah}

Berdasarkan latar belakang diatas, maka ada dua masalah yang dapat dirumuskan yaitu:
1. Apa saja faktor- faktor yang menyebabkan timbulnya kekerasan dalam rumah tangga?

2. Hambatan-hambatan apa saja yang terjadi dalam penegakan hukum bagi pelaku KDRT?

\section{PEMBAHASAN}

\subsection{Faktor- Faktor Yang Penyebab} Timbulnya Kekerasan Dalam Rumah

\section{Tangga (KDRT)}

Pengertian Kekerasan Dalam Rumah Tangga (KDRT) adalah kekerasan yang dilakukan di dalam rumah tangga baik oleh suami maupun istri, dan siapa saja yang tinggal dalam rumah tersebut. KDRT adalah segala bentuk tindak kekerasan yang terjadi atas dasar perbedaan jenis kelamin yang mengakibatkan rasa sakit atau penderitaan terhadap seseorang terutama terhadap perempuan baik ancaman, paksaan, pembatasan kebebasan, baik yang terjadi dalam lingkup publik maupun domestik. Sedangkan pengertian KDRT menurut Undang-undang Nomor 23 Tahun 2004 adalah setiap perbuatan terhadap seseorang terutama perempuan, yang berakibat timbulnya kesengsaraan atau penderitaan secara fisik, seksual, psikologis, atau penelantaran rumah tangga termasuk ancaman untuk melakukan perbuatan, pemaksaan, atau perampasaan 
kemerdekaan secara melawan hukum dalam lingkup rumah tangga.

Kekerasan berbasis gender merupakan jenis kekerasan dilakukan oleh seseorang terhadap jenis kelamin yang berbeda seperti laki-laki melakukan tindak kekerasan terhadap perempuan atau bisa jadi malah sebaliknya permpuan adalah pelakunya, namun berdasarkan data dilapangan perempuan lebih banyak menjadi korban daripada menjadi pelaku. Banyak faktor penyebab perempuan lebih dominan menjadi korban daripada laki-laki antara lain disebabkan terjadinya ketidaksetaraan dalam hungan baik dalam rumah tangga ataupun secara individu.

Secara bahasa, kekerasan berasal dari bahasa Inggris violence yang berati kuat atau kuasa. Menurut istilah, kekerasan berarti sebuah ekspresi baik yang dilakukan secara fisik ataupun verbal yang mencerminkan pada tindakan agresif dan penyerangan pada kebebasan atau martabat seseorang yang dapat dilakukan oleh perorangan atau sekelompok orang. Kekerasan adalah segala bentuk perbuatan yang menimbulkan luka baik secara fisik, psikis maupun secara verbal. Kekerasan merupakan suatu tindakan yang dilakukan oleh seseorang atau sejumlah orang kepada seseorang atau sejumlah orang, yang dengan kekuatannya, baik secara fisik maupun non-fisik dengan sengaja me- lakukan untuk menimbulkan penderitaan kepada orang lain.

Dari penjelasan diatas dapat disimpulkan bahwa KDRT merupakan segala bentuk tindakan kekerasan yang terjadi terhadap seseorang yang ada dalam satu atap rumah, namun biasanya perempuan dan anak lebih banyak menjadi korban daripada menjadi pelaku. KDRT mengakibatkan timbulnya penderitaan secara fisik, seksual, psikologis, atau penelantaran rumah tangga pada korban KDRT. KDRT dipandang sebagai fenomena sosial yang sulit untuk dihapuskan dan sulit terungkap, karena para korban menutup rapat masalah keluarganya karena mereka beranggapan bahwa permasalahan keluarga adalah aib yang tidak boleh diberitahukan kepada siapapun.

Dalam sebuah rumah tangga terdapat sepasang suami istri, anak-anak dan siapa saja yang tinggal didalam rumah tersebut. Rumah tangga akan menjadi tentaram dan bahagia pabalila dalam rumah tersebut tercipta hubungan yang harmonis, saling menghargai, saling menyayangi dan tidak ada kekerasan didalamnya. Ketidakharmonisan dalam rumah tangga terjadi karena adanya sesuatu yang timpang didalam rumah tangga tersebut, baik dari sikap maupun tutur kata dari orang yang ada di dalam rumah tersebut. Pada hakikatnya, membangun rumah tangga 
bertujuan membentuk rumah tangga yang sakinah, mawaddah dan warrahmah. Karena itu, pada hakikatnya tidak akan terjadi kekerasan apabila ketimpangan dalam keluarga tidak terjadi.

Budaya yang ada di Indonesia merupakan budaya patriarki, dimana perempuan masih dianggap menjadi makhluk nomor dua dan dalam keluarga adanya subordinasi. Hal ini juga yang menjadikan banyak perempuan menjadi korban kekerasan dalam rumah tangga. Ada beberapa faktor penyebab terjadinya KDRT yang terjadi di masyarakat, antara lain:

a. Budaya patriarki yang menempatkan posisi pihak laki-laki yang memiliki kekuasaan merasa lebih unggul. Dalam hal ini laki-laki dianggap lebih unggul daripada perempuan dan berlaku tanpa perubahan, bersifat kodrati. Pengunggulan laki-laki atas perempuan ini menjadikan perempuan berada pada posisi rentan menjadi korban KDRT.

b. Pandangan dan pelabelan negatif (stereotype) yang merugikan, misalnya laki-laki kasar, maco, perkasa sedangkan perempuan lemah, dan mudah menyerah jika mendapatkan perlakuan kasar. Pandangan ini digunakan sebagai alasan yang dianggap wajar jika perempuan menjadi sasaran tindak KDRT. c. Pemahaman agama yang tidak sesuai dengan nilai-nilai universal agama. Agama sering digunakan sebagai legitimasi pelaku KDRT terutama dalam lingkup keluarga, padahal agama menjamin hak-hak dasar seseorang, semisal laki-laki adalam pemimpin padahal kata Rijal maknanya bukan pada jenis kelamin namun pada sifat.

d. Masyarakat juga memiliki andil besar dalam terjadinya KDRT bagaimana tidak ketika seorang istri pulang malam karena dia bekerja malah menjadikan cibiran tetapi tidak sebaliknya jika seorang suami yang bekerja dan pulang malam malah justru diunggulkan dianggap dia sebagai seorang laki- laki yang pekerja keras.

e. Antara suami dan istri tidak saling memahami, dan tidak saling mengerti. Sehingga jika terjadi permasalahan keluarga, komunikasi tidak berjalan baik sebagaimana mestinya.

Jika berbicara tentang KDRT banyak bentuk-bentuk KDRT, meliputi: Pertama, kekerasan fisik yaitu perbuatan yang mengakibatkan rasa sakit, jatuh sakit atau luka berat. Kekerasan secara fisik baik dalam bentuk ringan maupun berat. Kekerasan fisik dalam bentuk ringan misalnya, mencubit, menjambak, memukul dengan pukulan yang tidak menyebabkan cidera dan sejenisnya atau bisa 
disimpulkan kekerasan yang bersifat fisik dampak kekerasan itu bisa dilihat. Sedangkan kekerasan fisik dalam bentuk berat misalnya, memukul hingga cidera, menganiaya, melukai, membunuh dan sejenisnya. Kedua, kekerasan psikis yaitu perbuatan yang mengakibatkan ketakutan, hilangnya rasa percaya diri, hilangnya kemampuan untuk bertindak, rasa tidak berdaya, dan atau penderitaan psikis pada seseorang.

Kekerasan psikis tidak tampak bukti yang dapat dilihat secara kasat mata, namun kekerasan psikis sering menimbulkan dampak yang lebih lama ada yang menyebabkan trauma. Ketiga, kekerasan seksual yaitu kekerasan yang berbentuk pelecehan seksual seperti ucapan, simbol dan sikap yang mengarah pada porno, perbuatan cabul, perkosaan dan sejenisnya. Pemaksaan hubungan seksual yang dilakukan terhadap orang yang menetap dalam lingkup rumah tangga. Pemaksaan hubungan seksual terhadap salah seorang dalam lingkup rumah tangganya dengan orang lain untuk tujuan komersial dan tujuan tertentu. Keempat, kekerasan ekonomi/ penelantaran rumah tangga yaitu kekerasan dalam bentuk penelantaran ekonomi pada umumnya tidak menjalankan tanggungjawabnya dalam memberikan nafkah dan hak-hak ekonomi lainnya terhadap istri, anak atau anggota keluarga lainnya dalam lingkup rumah tangga. Jika kita lihat bentuk-bentuk KDRT berdasarkan UU RI Penghapusan KDRT Nomor 23 Tahun 2004, sebagai berikut:

Setiap orang dilarang melakukan kekerasan dalam rumah tangga terhadap orang dalam lingkup rumah tangganya, dengan cara: a. Kekerasan fisik b. Kekerasan psikis c. Kekerasan seksual, dan d. Penelantaran rumah tangga.

Kekerasan fisik sebagaimana dimaksud dalam Pasal 5 huruf a adalah perbuatan yang mengakibatkan rasa sakit, jatuh sakit, atau luka berat.

Kekerasan psikis sebagaimana dimaksud dalam Pasal 5 huruf $\mathrm{b}$ adalah perbuatan yang mengakibatkan ketakutan, hilangnya rasa percaya diri, hilangnya kemampuan untuk bertindak, rasa tidak berdaya, dan/atau penderitaan psikis berat pada seseorang.

Kekerasan seksual sebagaimana dimaksud dalam Pasal 5 huruf c meliputi: a. Pemaksaan hubungan seksual yang dilakukan terhadap orang yang menetap dalam lingkup rumah tangganya tersebut. b. Pemaksaan hubungan seksual terhadap salah seorang dalam lingkup rumah tangganya dengan orang lain untuk tujuan komersial dan/tujuan tertentu.

(1) Setiap orang dilarang menelantarkan orang dalam lingkup rumah tangganya, padahal menurut hukum yang berlaku baginya atau karena persetujuan 
atau perjanjian ia wajib memberikan kehidupan, perawatan, atau pemeliharaan kepada orang tersebut. (2) Penelantaran sebagaimana dimaksud pada ayat (1) juga berlaku bagi setiap orang yang mengakibatkan ketergantungan ekonomi dengan cara membatasi dan/atau melarang untuk bekerja yang layak di dalam atau di luar rumah sehingga korban berada di bawah kendali orang tersebut.

Dari penjelasan diatas dapat disimpulkan bahwa bentuk-bentuk KDRT adalah pertama, kekerasan fisik yaitu kekerasan yang menyebabkan korban menderita fisik yakni sakit, jatuh sakit, atau luka yang diderita pada anggota tubuh korban kekerasan. Kedua, kekerasan psikis yaitu kekerasan yang menyebabkan korban trauma psikis yang ada pada dirinya, seperti takut. Ketiga, kekerasan seksual yaitu kekerasan yang memaksa atau menuntut korban untuk memenuhi segala kebutuhan biologis yang diinginkan pelaku kekerasan. Keempat, penelantaran rumah tangga yaitu kekerasan menelantarakan ekonomi anggota keluarganya, tidak menjalankan tanggungjawabnya, serta tidak memberikan nafkah atau hakhak kepada anggota keluarga.

Berdasarkan data yang dihimpun dari Pusat Pelayanan Terpadu (PPT) sebagai salah satu layanan untuk perempuan dan anak korban kekerasan bahwa jenis kekerasan yang paling banyak adalah kekerasan fisik yang kedua adalah psikis dan yang ketiga adalah penelantaran. Kekerasan terhadap perempuan dan anak terjadi karena banyak faktor, antara lain: ${ }^{1}$

a. Faktor individu perempuan, jika dilihat dari bentuk pengesahan perkawinan, seperti melalui kawin siri, secara agama, adat, kontrak, atau lainnya perempuan yang menikah secara siri, kontrak, dan lainnya berpotensi 1,42 kali lebih besar mengalami kekerasan fisik dan/atau seksual dibandingkan perempuan yang menikah secara resmi diakui negara melalui catatan sipil atau KUA. Selain itu, faktor seringnya bertengkar dengan suami, perempuan dengan faktor ini beresiko 3,95 kali lebih tinggi mengalami kekerasan fisik dan/atau seksual, dibandingkan yang jarang bertengkar dengan suami/pasangan. Perempuan yang sering menyerang suami/pasangan terlebih dahulu juga beresiko 6 kali lebih besar mengalami kekerasan fisik dan/atau seksual dibandingkan yang tidak pernah menyerang suami/pasangan lebih dahulu.

b. Faktor pasangan, perempuan yang suaminya memiliki pasangan lain beresiko 1,34 kali lebih besar mengalami kekerasan fisik dan/atau seksual dibandingkan perempuan yang

\footnotetext{
${ }^{1}$ www.kemenppa.go.id diakses pada tanggal 1 juli 2019 pada jam 20.30 WIB
} 
suaminya tidak mempunyai istri/pasangan lain. Begitu juga dengan perempuan yang suaminya berselingkuh dengan perempuan lain cenderung mengalami kekerasan fisik dan/atau seksual 2,48 kali lebih besar dibandingkan yang tidak berselingkuh. Disamping itu, ada pula perempuan yang memiliki suami menggangur beresiko 1,36 kali lebih besar mengalami kekerasan fisik dan/atau seksual dibandingkan yang pasangannya bekerja/tidak menganggur. Faktor suami yang pernah minum miras, perempuan dengan kondisi suami tersebut cenderung 1,56 kali lebih besar mengalami kekerasan fisik dan/atau seksual dibandingkan yang suaminya tidak pernah minum miras. Begitu juga dengan perempuan yang memiliki suami suka mabuk minimal seminggu sekali, beresiko 2,25 kali lebih besar mengalami kekerasan fisik dan/atau seksual dibandingkan yang tidak pernah mabuk.Perempuan dengan suami pengguna narkotika beresiko mengalami kekerasan fisik dan/atau seksual 2 kali lebih besar dibandingkan yang tidak pernah menggunakan narkotika. Perempuan yang memiliki suami pengguna narkotika tercatat $45,1 \%$ mengalami kekerasan fisik, 35,6\% mengalami kekerasan seksual, $54,7 \%$ mengalami kekerasan fisik dan seksual, 59,3\% mengalami kekerasan ekonomi, 61,3\% mengalami kekerasan emosional/psikis, dan yang paling tinggi yaitu $74,8 \%$ mengalami kekerasan pembatasan aktivitas. Selain itu faktor suami yang pernah berkelahi fisik dengan orang lain, perempuan dengan suami kondisi ini beresiko 1,87 kali lebih besar mengalami kekerasan fisik dan/atau seksual dibandingkan yang tidak pernah berkelahi fisik.

c. Faktor ekonomi, perempuan yang berasal dari rumahtangga dengan tingkat kesejahteraan yang semakin rendah cenderung memiliki risiko yang lebih tinggi untuk mengalami kekerasan fisik dan/atau seksual oleh pasangan. Perempuan yang berasal dari rumahtangga pada kelompok $25 \%$ termiskin memiliki risiko 1,4 kali lebih besar mengalami kekerasan fisik dan/atau seksual oleh pasangan dibandingkan kelompok $25 \%$ terkaya. Aspek ekonomi merupakan aspek yang lebih dominan menjadi faktor kekerasan pada perempuan dibandingkan dengan aspek pendidikan. Hal ini paling tidak diindikasikan oleh pekerjaan pelaku yang sebagian besar adalah buruh, dimana kita tahu bahwa tingkat upah buruh di Indonesia masih tergolong rendah dan hal ini berdampak pada tingkat kesejahteraan rumahtangga. 
d. Faktor sosial budaya, seperti timbulnya rasa khawatir akan bahaya kejahatan yang mengancam. Perempuan yang selalu dibayangi kekhawatiran ini memiliki risiko 1,68 kali lebih besar mengalami kekerasan fisik dan/atau seksual oleh pasangan, dibandingkan mereka yang tidak merasa khawatir. Perempuan yang tinggal di daerah perkotaan memiliki risiko 1,2 kali lebih besar mengalami kekerasan fisik dan/atau seksual oleh pasangan dibandingkan mereka yang tinggal di daerah pedesaan.

Sedangkan dalam penelitian ini faktor-faktor yang melatarbelakangi terjadinya kekersan dalam rumah tangga antara lain:

a. Faktor Pendidikan

b. Faktor Pernikahan dibawah umur

c. Faktor Ekonomi

d. Faktor Budaya

e. Faktorketerlibatan Pihak ketiga

Dari sekian banyak faktor yang memicu terjadinya KDRT, perlu dipahami bahwa pentingnya kesetaraan dalam keluarga yang perlu diimplemtasikan sehingga ada pembagian peran atau kerja sehingga tidak menajdi beban seorang perempuan saja. Ada pula yang perlu kita ingat bahwa komunikasi dalam keluarga itu perlu dibangun sehingga tercipta suasana lingkungan keluarga yang harmonis dan sejahtera.
2.2.Hambatan-Hambatan

Dalam

Penegakan Hukum Kekerasan

\section{Dalam Rumah Tangga}

Keluarga adalah unit terkecil dari masyarakat yang terdiri atas kepala keluarga dan beberapa orang yang ada dalam satu atap dimana semua orang yang ada didalamnya bersifat saling ketergantungan. Rumah seharusnya merupakan tempat yang paling aman, namun tidaklah demikan terkadang yang terjadi justru sebaliknya seringkali terjadi kekerasan didalam rumah tangga. Tujuan seseorang berumah tangga seharusnya adalah untuk memperoleh keluarga yang sakinah, mawaddah dan rahmah, justru tindak kekerasan yang dialaminya. Kekerasan tersebut banyak terjadi dirumah dan korbannya paling banyak adalah pihak perempuan.

Berdasarkan hasil penelitian dengan cara membagikan quisoner kepada 30 perempuan dilingkungan Tegalgede, Kelurahan Sumbersari Kabupaten Jember, hambatan atau kendala yang dialami sehingga mereka tidak mengungkapkan kekerasan dalam rumah tangga yang dialaminya, antara lain sebagai berikut :

a. Tidak tahu kemana mereka akan melapor; Berdasarkan hasil quisioner diperoleh data bahwa mereka tidakmengetahui kemana mereka akan melapor bila mengalami kekerasan dalam rumah tangga. Hal ini karena 
minimnya pengetahuan yang dimiliki masyarakat dengan ekonomi lemah. Selain itu sosialisai bagi masyarakat miskin terutama kaum perempuan yang kebanyakan dari mereka bekerja diranah domestik, jarang sekali mereka peroleh. Bahkan sebagian besar mereka menyampaikan bahwa mereka tidak tahu bagaimana caranya melaporkan tindakan kekerasan yang terjadi.

b. Masing menganggap hal itu adalah ranah privasi keluarga: Kekerasan yang terjadi dalam lingkup rumah tangga masih dianggap sebagai masalah individu dan bersifat sangat pribadi, sehingga masyarakat masih enggan untuk ikut campur meskipun mereka mengetahu telah terjadi kekerasan. Langkah ini ditempuh karena dikhawatirkan akan berdampak yang kurang baik pada hubungan dalam bertetangga diantara anggota masyarakat di lingkungan mereka.

c. Dianggap sebagai aib keluarga:

Kebanyakan dari mereka yang mengalami kekerasan dalam rumaha tangga masih menganggap bahwa permasalahan yang terjadi di rumah tangga mereka merupakan aib yang tidak boleh siapapun mengetahuinya. Dengan demikian permasalahan yang sedang terjadi dan dialami dalam rumah tangga mereka, mereka lebih memilih untuk menyimpan semua permasalahan yang terjadi daripada melaporkannya kepada pihak yang berwajib.

d. Ajaran agama yang ditafsirkan secara salah: Masih banyak dikalangan anggota masyarakat yang meyakini bahwa agama mereka mengajarkan yang memperbolehkan untuk melakukan kekerasan kepada istrinya. Misalnya ajaran tentang bolehnya memukul istri ketika istri berbuat salah yaitu: "Ketika istrimu berbuat salah, maka diperintahkan untuk dipukul".Ajaran semacam ini masih dipahami secara letterlijk atau tekstual saja, sehingga apabila istri melakukan suatu perbuatan yang dianggap salah oleh suaminya, maka si suami akan langsung melakukan pemukulan atau tindak kekerasan kepada istrinya. Padahal maksud dari ajaran tersebut tidaklah demikian pengertian yang seharusnya.

e. Tergantung secara ekonomi: Kebanyakan dari mereka tidak bekerja secara formal, mereka hanya bekerja di rumah menjadi ibu rumah tangga sehingga untuk memenuhi biaya keperluan sehari-hari mereka menunggu nafkah atau pemberian dari suami mereka. Ada pula sebagian dari mereka yang bekerja sebagai buruh harian yang memperoleh penghasilan sangat kecil, sehingga tidak mencukupi 
untuk memenuhi kebutuhan seharihari. Kelompok yang kedua ini memenuhi biaya keperluan sehari-hari mereka juga menunggu pemberian nafkah dari suami mereka

f. Bertahan demi anak: Salah satu dilema yang dialami oleh para korban kekerasan dalam rumah tangga adalah persoalan anak. Problem dilematis tersebut adalah jika mereka melaporkan tindak kekerasan yang terjadi dalam rumah tangganya, mereka menjadi takut jika suami mereka benarbenar menjalani proses hukum dan ditahan oleh pihak berwajib, maka anak-anaknya akan menjadi korban bullying oleh teman-temannya. Selain hal itu, yang lebih mereka takutkan lagi adalah apabila mereka berpisah dengan suaminya, maka si suami tidak akan lagi memberikan nafkah untuknya dan anak-anak mereka.

Jika melihat kendala dalam penegakan hukum di masyarakat terkait dengan kekerasan dalam rumah tangga, sebetulnya sebagian besar mereka yang menjadi korbankekerasan dalam rumah tangga tersebut belum memahami atau belum mengetahui tentang apa saja hakhak mereka ketika menjadi korban padahal mereka mereka sudah dilindungi secara hukum. Hak-hak korban kekerasan dalam rumah tangga tersebut berdasarkan ketentuan Pasal 10 Undang-Undang
Nomor 23 Tahun 2004 tentang Penghapusan Kekerasan dalam Rumah Tangga, sebagai berikut:

1. Perlindungan dari pihak keluarga, kepolisian, kejaksaan, pengadilan, advokat, lembaga sosial, atau pihak lainnya baik sementara maupun berdasarkan penetapan perintah perlindungan dari pengadilan.

2. Pelayanan kesehatan sesuai dengan kebutuhan medis.

3. Penanganan secara khusus berkaitan dengan kerahasiaan korban.

4. Pendampingan oleh pekerja sosial dan bantuan hukum pada setiap tingkat proses pemeriksaan sesuai dengan ketentuan peraturan perundangundangan.

5. Pelayanan bimbingan rohani.

\section{PENUTUP}

\subsection{Kesimpulan}

1. Berdasarkan hasil penelitian yang dilakukan oleh peneliti terhadap responden warga Kelurahan Tegalgede,faktor-faktor yang menjadi penyebab terjadinya kekerasan dalam rumah tangga adalah pertama faktor ekonomi, kedua pendidikan, ketiga budaya dimana dalam masyarakat ini masih kuat untuk budaya patriarkhi, dimana semua pekerjaan di rumah merupakan taggung jawab pihak 
perempuan. Keempat, adanya keterlibatan pihak ketiga, yaitu pihak ketiga ini bukan hanya adanya perempuan atau laik-laki lain yang merusak hubungan rumah tangga, namun juga adanya campur tangan dari orang tua atau mertua juga ikut terlibat dalam munculnya perbuatan kekerasan dalam rumah tangga.

2. Hambatan-hambatan yang timbul dalam penegakan hukum dalam rumah tangga antara lain: korban kekerasan enggan untuk melaporkan terjadinya kekerasan yang dialaminya karena mereka menganggap kekerasan yang menimpa dirinya masih dianggap sebagai aib kelaurga.Pada saat kasus kekerasan sudah dilaporkan kepada pihak berwajib, mereka terkadang mencabut laporan yang sudah diadukan dengan alasan kasihan kepada anakanaknya dan mereka takut anaknya akan dibully oleh teman-teman dan tetangganya.

\subsection{Saran}

1. Perlu dilakukan kegiatan sosialisasi yang menyeluruh kepada semua lapisan masyarakat mengenai bagaimana prosedur pelaporan apabila terjadi atau mengalami kekerasan dalam rumah tangga.

2. Perlu ada lembaga pelayanan pada tingkat kelurahan yang memberikan pelayanan kepada korban yang mengalami kekerasan dalam rumah tangga dan mempermudah untuk melapor.

3. Perlu peningkatan peran serta para tokoh agama dalam melakukan sosialisasi bahwasanya kekerasan itu dilarang oleh ajaran agama.

4. Perlu ada kegiatan pelatihan-pelatihan yang bertujuan untuk melatih kemandirian secara ekonomi bagi perempuan ekonomi lemah sehingga mereka mampu dan mandiri secara ekonomi dan tidak bergantung sepenuhnya kepada suami.

\section{DAFTAR PUSTAKA}

Abdulsyani. 2002. Sosiologi Skematika, Teori Dan Terapan. Jakarta : Bumi Aksara Ahmad, Imam. 1993. Perempuan Dalam Kebudayaan (dalam buku Dinamika Gerakan Perempuan Indonesia ). Yogyakarta: PT Tiara Wacana

Anna, Sakreti. 2004. Peliknya Penanganan KDRT. Kompas Senin 12 Juli 2004 Alsa, Asmadi. 2004. Pendekatan Kualitatif dan Kuantitatif Serta Kombinasinya DalamPenelitian Psikologi. Yogyakarta : Pustaka Pelajar 
Astuti, Puji. 2002. Kemandirian dan Kekerasan Terhadap Istri. Bulletin psikologi. Tahun X. No. 2

Azwar, Saifuddin. 1997. Metode Penelitian. Yogyakarta : Pustaka Pelajar Berry, John dkk. 1999.

Djanah, F. 2003. Kekerasan Terhadap Istri. Yogyakarta : LKIS Erna, Zuraida Yuni W. 2006.

Fakih Mansour, Diskriminasi dan Beban Kerja Perempuan, Perspektif Gender, Cidesindo, Yogyakarta, 1998.

Gosita, Arif, Masalah Perlindungan Anak. Jakarta: Akademika Pressindo CV, 1984.

Hanum, F.2006. Perempuan dan Kekerasan dalam rumah tangga .Yogyakarta : Univeristas Negeri Jogyakarta

Herlina, Apong, dkk.,Perlindungan Anak: Berdasarkan Undang-Undang Nomor 23 Tahun 2002 tentang Perlindungan Anak. Jakarta: UNICEF, 2005.

Kartini Kartono. 2004 . Psikologi Wanita, Bandung
Kompas. Kekerasan Terhadap Perempuan Meningkat Hampir Dua Kali Lipat. 07 Maret 2005

Moeljatno. 2004 . Azaz-Azaz Hukum Pidana, Bina Aksara, Jakarta

Moleong. J. 2000. Metode Penelitian Kualitatif. Bandung : PT Remaja Rosda Karya

\section{Peraturan-Peraturan:}

UU Nomor 23 Tahun 2004 Tentang Penghapusan Kekerasan Dalam Rumah Tangga;

UU Nomor 35 Tahun 2014 Tentang Perubahan Dari Undang-Undang Nomor 23 Tahun 2002 Tentang Perlindungan Anak

Internet :

http://www.hukumonline.com/

http://www.kompas.org

http://www.kemenpppa.go.id/ 2019

http://repository.unej.ac.id/bitstream/handl e/123456789/57903/6.\%20Pendahuluan.p $\underline{d f ? \text { sequence }=6}$ 


\section{BIODATA SINGKAT PENULIS}

Solehati Nofitasari adalah dosen tetap pada Program Studi Ilmu Hukum Fakultas Hukum Universitas Islam Jember. Menyelesaikan Pendidikan sarjana Hukum pada Program Studi Ilmu Hukumdi Universitas Muhammadiyah Jember dan S2 Hukum Pidana Universitas Jember tahun 2014.

Supianto adalah Dosen tetap pada Fakultas Hukum Universitas Islam Jember. Menyelesaikan pendidikan Sarjana Hukum pada Fakultas Hukum Universitas Islam Jember dan Magister Hukum pada Program Magister Ilmu Hukum Fakultas Hukum Universitas Jember tahun 2012. 